\title{
Application of "sustainable development" computer program in development of scientific and research competence in the study of discipline "urban ecology"
}

\author{
I. Soloshych \\ Kremenchuk Mykhailo Ostrohradskyi National University, Kremenchuk, Ukraine \\ Corresponding author. E-mail: soloishych@gmail.com
}

Paper received 01.05.18; Accepted for publication 05.05.18.

\begin{abstract}
http://doi.org/10.31174/SEND-PP2018-165VI69-08
\end{abstract}
Abstract. The study considers the process of formation of scientific and research competence of future environmental specialists in studying the discipline "Urban ecology." The article outlines questions, which are studied by the students at the lectures and practical classes for determination of the level of socio-ecological and economic conditions of urban, geological and social systems using the developed computer program "Sustainable development." It is determined that the formation of scientific research competence of future environmental specialists using the program "Sustainable development" contributes to the creation of an innovative environment that promotes the maximum development of research and scientific potential and stimulates the need for creative self-development.

Keywords: scientific research competence, future environmental specialists, the computer program "Sustainable development".

Introduction. The acuteness of the environmental situation has led to an understanding of the need to the immediate transition to a new model of social development - sustainable development, which involves the implementation of innovative reforms in the ecology, economy, the introduction of the latest energy-saving and information technologies.

Therefore, the training of future environmental specialists (FESs) requires the use of computer training software in the educational process, which provides the opportunity to more systematically and efficiently carry out scientific research tasks in the field of environmental protection in professional activities.

Analysis of recent research and publications. According to many scientists (O. Vladimirova, G. Biletska, V. Bogolyubov, etc.), a modern environmental specialist should be a researcher, because his further professional activity is determined by the rapid changes in the world ecology, on which scientific achievements have a direct impact.

The ways of introducing software in the educational process of institutions of higher education (IHE) have been analyzed in the works of R. Gurevich, V. Glushkov, M. Zhaldak, I. Podlasogo, S. Sysoevoy, and others.

However, as the analysis of scientific literature proves, the problem of the use of computer software teaching in the formation of scientific research competence (SRC) in the course of studying the discipline "Urban ecology" was not the subject of an independent study.

The aim of the study. The purpose of the work is to use the computer program "Sustainable development" (Program) in developing the research competence in the process of studying the discipline "Urban ecology".

Materials and methods of research. The research used the following methods: general scientific analysis, synthesis; theoretical - the analysis of scientific, educational and methodical literature on pedagogy concerning the introduction of information and communication technologies in the educational process, as well as issues of formation of scientific research competence (SRC) of the future environmental specialists in the study of the educational discipline "Urban ecology".

Results of the research and their discussion. None of the areas of human activity is currently operated without information technology. The use of information technologies is a priority trend in the development of modern society, in which, according to D. Bella, the main productive force is science-based technologies, and its potential is measured by the amount of information used [1, p. 333].
We share the point of G. Beletskaya [2, p. 251] that environmental education is the most expensive education, which requires a certain material and technical base, laboratory equipment, which either is absent in many institutions of higher education of Ukraine or is morally and physically obsolete. Most natural processes are time-consuming, so the use of computer software allows to simulate natural processes, predict their changes as a result of anthropogenic influences, conduct virtual experiments, which contributes to the process of SRC formation in future environmentalists.

Since the formation of SRC in the FES is a system of pedagogically organized interaction of its participants, as well as an information process related to the creation, analysis, conservation, exchange and use of environmental information, it is considered that implementation of the information technologies influences the content of education and the choice of methods and means of training.

Hence, the current priority direction of the activity of IHE in preparation of the FES is such an organization of the educational process, in which each student could become the subject of his own development, acquire and process educational and scientific information through independent scientific, cognitive and research activities. After all, the FES must not only have sufficient experience of implementing known methods of activity (forecasting, modelling, designing, designing), but also the ability to conduct a qualified research.

Now we shall consider the process of forming the SRC in the FES when studying the discipline "Urban ecology", which is embedded in the curriculum of preparation of bachelors of the field of knowledge 6.040106 "Natural sciences" for the direction of preparation 6.040106 "Ecology, environmental protection and sustainable use of nature resources" [3].

In accordance with Appendix B [3, p. 133], the discipline "Urban ecology" refers to the cycle of professional and practical training and is studied in the third year for two semesters. The purpose of the discipline is to teach students to analyze the structure, functions, current state of urban, geological and social systems (UGSS), determine the level of their socio-ecological-economic status (SEES) and on the basis of their analysis and acquired SRC, to optimize the urbanized environment.

For this purpose, the FESs, in accordance with the curriculum of "Urban ecology", study the methodology of integrated assessment of the socio-ecological and economic development of the UGSS at lectures and practical classes. 
An analysis of works $[4,5]$ allowed us to conclude that the most successful and comprehensive method is the one that was proposed by A. Prishchepa and L. Klymenko [5].
The table lists the issues that are being studied to determine the level of SEES of UGSS in studying the discipline "Urban ecology".

Table. - Topics and questions that are being studied to determine the level of the socio-ecological and economic state of the urban geological and social systems.

\begin{tabular}{|c|c|c|}
\hline The title of the unit & The title of the topic & Questions \\
\hline \multirow{3}{*}{$\begin{array}{l}\text { 1. Urbanization, its } \\
\text { factors, trends and } \\
\text { consequences for } \\
\text { the environment and } \\
\text { human }\end{array}$} & $\begin{array}{l}\text { 3. The methodology of Integrated As- } \\
\text { sessment of the SEES of the UGSS. }\end{array}$ & $\begin{array}{l}\text { Aggregated indicators. Integrated Indicators. Integral index of the SEES of the } \\
\text { UGSS }\end{array}$ \\
\hline & 4. Social development of the UGSS & $\begin{array}{l}\text { Indicators: indicators of the living standard protection, demographic, population, } \\
\text { morbidity and housing }\end{array}$ \\
\hline & 5. Economic Development of the UGSU & $\begin{array}{l}\text { Indicators: industrial and economic development, incomes and unemployment of } \\
\text { the population }\end{array}$ \\
\hline $\begin{array}{l}\text { 2. Ecological state } \\
\text { of the UGSS }\end{array}$ & $\begin{array}{l}\text { 6. Characteristics of the ecological state } \\
\text { of the UGSS }\end{array}$ & $\begin{array}{l}\text { Physical-geographical, climatic hydrological conditions, relief, soil cover charac- } \\
\text { teristics }\end{array}$ \\
\hline \multirow[t]{5}{*}{$\begin{array}{l}\text { 3. Anthropogenic } \\
\text { pollution of the } \\
\text { UGSS }\end{array}$} & $\begin{array}{l}\text { Topic 13. Pollution of atmospheric air of } \\
\text { the UGSS }\end{array}$ & $\begin{array}{l}\text { Indicators: total emissions of pollution elements; emissions and density from } \\
\text { stationary and mobile sources; the number of pollution elements per capita }\end{array}$ \\
\hline & 14. Pollution of water resources & Indicators: the capture and use of water; control and quality of drinking water \\
\hline & $\begin{array}{l}\text { 15. Pollution of land resources of the } \\
\text { UGSD }\end{array}$ & $\begin{array}{l}\text { Indicators: land structure; area of agricultural land, disturbed lands; contaminated } \\
\text { with radionuclides and heavy metals }\end{array}$ \\
\hline & 16. Waste generation and management & $\begin{array}{l}\text { Indicators: Waste generation and utilization; Areas occupied by landfills; compli- } \\
\text { ance with sanitary and ecological requirements; waste recycling; toxic waste }\end{array}$ \\
\hline & $\begin{array}{l}\text { 18. The computer program "Sustainable } \\
\text { Development" }\end{array}$ & $\begin{array}{l}\text { A computer program "Sustainable Development" for the definition of the CPSU } \\
\text { of the UGSS. Calculation of basic, aggregated, integrated indicators, integral } \\
\text { development index of the UGSS. Visualization of the calculation }\end{array}$ \\
\hline
\end{tabular}

Due to the accumulation of a large amount of information on the definition of the CEEC of the country as a whole and its individual urbanized regions, the problem of its systematization, calculation of indicators, visualization and preservation of the received data becomes especially acute.

We have developed a computer program "Sustainable development", described in the author's work [6], which can be used by scientists in determining the state of the socioecological and economic state of UGSS, modeling the strategy of sustainable development of the country, environmental specialists in solving professional problems, students of ecological faculties during research and practical classes.

The developed Program, in accordance with the methodology [5], calculates the SEES using a system of basic indicators, combined in homogeneous groups (social, ecological, economic). The algorithm of calculation involves four levels of assessment and aggregation of indicators [7]: statistical informative baseline indicators (BI), which characterize the SEES of the subsystem of the environment; aggregate indicators (AI) that characterize the condition of related group (macro indicators) of subsystems under study; integrated indicators (II) that characterize the state of the SEES subsystem; SEES Integrated Development Index (SEESIDI).

With the help of the Program, the following steps are taken: calculation of BI, AI, II, SEESIDI of any UGGS of the area, region, country as a whole; calculation of the value of SEESIDI of the country, accompanied by the definition of the state according to the scale (critical, threatening, satisfactory, favorable) in the appropriate color and text transcription; the calculation of the country's SEESIDI using SEESIDI in each region.

When studying the discipline "Urban ecology", FESs in the first semester on lecture (Table) lessons study the method of evaluation of SEES of UGSS. When performing practical classes in calculating the SEES of urbanized regions, students collect and analyze information and make decisions about their search, ask themselves and the teacher questions of research direction.

This prompts them to seek answers - self-extracting knowledge. Having the knowledge gained on their own, they are more prepared for new professional challenges and further actions.

In the practical classes "Assessment of the social development of urban ecological social systems" and "Assessment of the economic development of UGSSS" in accordance with the given UGSS the students analyze their main indicators: indicators of protection of living standards, demographic, population morbidity and housing, production and economic development, incomes and unemployment rate of the population.

When performing the practical lesson "Characteristics of the ecological state of UGSS", the FESs, in accordance with the given UGSS, study the natural conditions of the region: information about the area and its physical and geographical location, climate, relief, hydrological conditions, characteristics of soil cover.

In the second semester the students during the implementation of practical classes of "Assessment of atmospheric air pollution of UGSS" and "Assessment of pollution of water and land resources of UGSS" are issued independent research, the purpose of which is to determine the natural resource potential of the selected region of research (indicators of the state of atmospheric air, soil, water resources, and waste management).

When conducting a practical lesson "Computer program" Sustainable Development" to determine the socio-ecological and economic state of UGSS with its use, the FESs are given the task in accordance with a given study area to determine and analyze the dynamics of the change of the SEES. Students collect, analyze, and then input the received data into the corresponding fields of the Program (Fig. 1).

The next step is to get the results of the research of the index of the selected component in numerical, textual and graphic formats.

To calculate the country's SEESIDI through the Program, the following steps are taken: calculation of BI, AI, II, SEESIDI of the urbanized area, region; output of the SEESIDI of the area on the map, accompanied by the definition of the condition according to the scale (critical, threatening, satisfactory, favorable) by the appropriate color and text signa- 
ture; calculation of the country's SEESIDI, using SEESIDI in each region.

During the course of practical classes the students analyzed the dynamics of indicators of the SEES of UGSS in the Poltava, Lviv, Mirgorod, Kharkiv, and Kirovograd regions, oblasts for the period 2000-2017 yy., and carried out a classification of their condition.

Problems associated with each region of the study are handled by students in the performance of individual research tasks are necessarily discussed in the groups.

Research, the search for new information, contributes to the formation of research competencies in the FES and the desire to continue the research. Therefore, despite the fact that the study of the topic is over, the FESs, being motivated, often decide to continue research in this direction.

The result of this is the master's work on studying the socio-ecological and economic condition of UGSS of Poltava, Lviv, Mirgorod, Kharkiv and Kirovograd regions, and the taken second place by the student Potebnaya D.V. in the AllUkrainian competition of student's scientific papers in the specialty "Economics of Natural Resources and Environmental Protection environment", entitled "Assessment of socio-ecological and economic indicators on the example of administrative districts of Poltava and Kharkiv regions", 2018.

\section{REFERENCES}

1. Bell D. Social Dimensions of the Information Society [Electronic resource] / Daniel Bell / / New Technocratic Wave in the West / ed. P.S. Gurevich - M.: Progress, 1986. - P. 330-342. - Access mode: http://nethistory.ru/biblio/1043172230.htm.

2. Biletska G. A. Theoretical and methodological principles of natural-scientific preparation of future ecologists in higher educational institutions: Dis ... Dr Ped. Sciences: 13.00.04 / Galina Anatolievna Biletska. - Vinnytsya: BB, 2015. - 537 p.

3. Educational-qualification characteristic and educationalprofessional program of bachelor, the direction of preparation 6.040106 "Ecology, environmental protection and sustainable use of nature". The branch standard of higher education of Ukraine, approved by the Ministry of Education and Science of Ukraine of 27.12.2011, No. 1543. - Odessa: TPP, 2012. - 116 p.

4. A new global partnership: eradicate poverty and transform economies through sustainable development. UN Report, 2013, 68

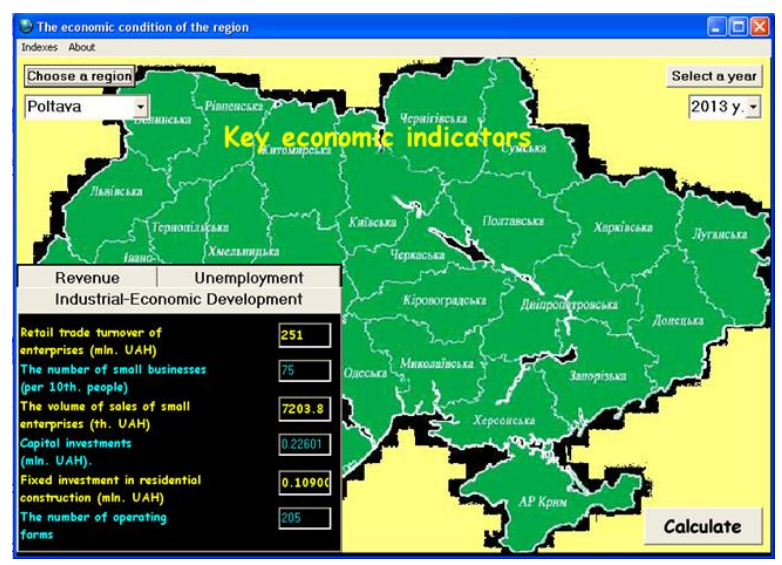

Fig. 1. Input data example

Conclusions. The formation of a SRC by a future environmental specialist with the use of the Program in studying the discipline Urban ecology involves the creation of an innovative environment that promotes the maximum development of the research-based potential inherent in the individual, stimulates the need for self-knowledge, creative selfdevelopment, implements the scientific cooperation of the teacher and students, ensuring psychological comfort during the study due to the availability of learning content that allows mobile adaptation to changes in professional activities that are caused by the rapid development of science.

pages. Available at: http://www.post2015hlp.org/wpcontent/uploads/2013/05/UN-Report.pdf .;

5. Pryschepa A.M. Methodical recommendations for calculating the socio-economic-ecological development index of the area // A. M. Pryshchepa, L. V. Klymenko. - Rivne, 2009. - 32 p.

6. Pochtovyuk S.I., Soloshich I.O. The computer program "Software application for the automated complex assessment of the sustainable development of the region". Certificate of registration of copyright for work No. 71266 dated April 3, 2017, application No. 72011 dated February 8, 2017.

7. Nekos A.N. Comprehensive assessment of regional development as a component of green economy implementation. A.N. Nekos, I.O. Soloshich. Actual problems of the economy. - 2014. - No. 5. - p. 99-112.

Применение компьютерной программы «sustainable development» при формировании научно-исследовательской компетентности в процессе изучения дисциплины «урбоэкология»

\section{И. А. Солошич}

Аннотация. В ходе исследования рассмотрен процесс формирования научно-исследовательской компетентности будущих специалистов-экологов при изучении учебной дисциплины «Урбоэкология».

Приведены вопросы, которые изучаются студентами на лекционных и практических занятиях для определения уровня социоэколого-экономического состояния урбогеосоциосистем с использованием разработанной компьютерной программы «Sustainable development». Определено, что формирование научно-исследовательской компетентности у будущего специалиста-эколога с использованием программы «Sustainable development» способствует созданию инновационной среды, которое способствует максимальному развитию научно-исследовательского потенциала и стимулирует потребность в творческом саморазвитии.

Ключевые слова: научно-исследовательская компетентность, будущие спечиалисты-экологи, компьютерная программа «Sизtainable development». 